\title{
Identifikasi penyebab kenaikan berat badan pada anak usia dini
}

\author{
Rahmat Sanusi $^{1 *}$, Widiyanto Widiyanto ${ }^{2}$, Ronny Brayntin Rahail ${ }^{3}$ \\ ${ }^{1}$ Universitas Karimun. Jalan. Canggai Putri Kec. Tebing, Kab. Karimun, Kep. Riau, 29663, Indonesia \\ ${ }^{2}$ Universitas Negeri Yogyakarta. Jalan Colombo No. 1, Yogyakarta 55281, Indonesia. \\ ${ }^{3}$ Universitas Musamus Merauke. Jl. Kamizaun Mopah Lama, Rimba Jaya, Kec. Merauke, Kabupaten \\ Merauke, Papua 99611, Indonesia. \\ * Corresponding Author. Email: rahmatsanusi25@gmail.com
}

Received: 17 February 2020; Revised: 28 April 2020; Accepted: 24 July 2020

\begin{abstract}
Abstrak: Upaya pencegahan masalah berat badan berlebih menjadi fokus utama saat ini berdasarkan peningkatan resiko kesehatan akibat overweight dan obesitas, teruatama pada anak-anak. Penelitian ini bertujuan untuk mengindentifikasi penyebab kenaikan berat badan pada anak usia dini dengan metode penelitian cross sectional. Jumlah subjek penelitian terdiri dari enam puluh enam anak. Teknik analisa yang digunakan adalah analisis multivariat. Hasil penelitian menujukkan terdapat hubungan bermakna $(\mathrm{p}<0.05)$ antara variabel varian terhadap kenaikan berat pada anak usia dini. Hasil penelitian disimpulkan bahwa faktor rendahnya aktivitas fisik, genetik dari orang tua dan pola makan berhubungan terhadap kenaikan berat badan pada anak usia dini.
\end{abstract}

Kata Kunci: overweight, obesitas dan anak usia dini

\section{Identify the causes of weight gain in early childhood}

Abstract: Today, the efforts to prevent weight gain excess become the main focus base on increased health risk consequences of overweight and obesity, especially in childhood. This research to investigate the factors that affect the incidence of overweight/obesity in childhood with an ex post facto research method. The total subject for this research was sixty-six children with data analysis using multivariate analysis. The results of this research are showing there is a significant correlation between variants variable on the increased weight gain excess in childhood. Finally, inactive physical activity, genetic, and diet are related to weight gain excess in childhood.

Keyword: overweight, obesity and childhood

How to Cite: Sanusi, R., Widiyanto, W., \& Rahail, R. (2020). Identifikasi penyebab kenaikan berat badan pada anak usia dini. Jurnal Keolahragaan, 8(2), 108-116. doi:https://doi.org/10.21831/jk.v8i2.30233

\section{PENDAHULUAN}

Masalah kelebihan berat badan menjadi masalah serius yang dihadapi oleh dunia saat ini. World Health Organization (WHO) telah menetapkan kelebihan berat badan (overweight dan obesitas) sebagai wabah di era urban, ditandai dengan meningkatnya prevalensi overweight dan obesitas hampir disemua negara terutama di negara-negara berkembang. Meningkatnya prevalensi overweight dan obesitas telah mencakup disemua lapisan yaitu orang dewasa, remaja hingga anak-anak yang menjadi bagian dari dampak kemajuan era urban dan digitalisasi saat ini. Obesitas pada anak, remaja dan dewasa menjadi satu dari sekian banyak masalah kesehatan dimasyarakat pada abad ke-21. Güngör (2014) menyebutkan bahwa telah terjadi peningkatan prevalansi obesitas pada anak-anak dalam tiga dekade terakhir yang sangat mengkhawatirkan mengingat kenaikannya yang terus mengalami kenaikan.

de Onis et al. (2010) menyebutkan bahwa beberapa tahun terakhir meningkatnya prevalensi overweight dan obesitas pada anak usia 5 tahun hampir diseparuh dunia yang berarti meningkatnya jumlah anak dengan resiko kesehatan. Konsep pertumbuhan anak dengan istilah "berat berarti sehat, semakin besar semakin baik" beredar luas dimasyarakat dan dianggap positif bagi sebagian orang tua. Konsep ini sangat diterima oleh orang tua yang menganggap pertambahan berat badan pada anak merupakan hal yang wajar dan normal dikarenakan dalam masa pertumbuhan. Ungkap tersebut sepenuhnya tidak benar, 
mengingat tingginya prevalensi overweight dan obesitas berdampak pada perkembangan fisiologis dan psikologis anak. Pada fase ini anak dituntut untuk dapar dapat beraktivitas secara aktif guna menunjang tumbuh dan kembangnya.

Kasus berat badan berlebih berdampak buruk dan dikaitkan pada resiko kesehatan terutama pada anak usia dini dengan rentang usia 3 sampai 5 tahun yang berpotensi mengalami gangguan pada sistem pernapasan yakni asma yang lebih tinggi dari pada anak dengan berat badan normal. Asma dipicu dengan menyempitnya saluran pernafasan yang salah satunya dipengaruhi oleh pernafasan diafrgma. Selain asma, diabetes tipe II menjadi resiko penyakiti yang sangat diwaspadai menyerang pada anak usia dini. Diabetes yang bersifat turunan genetik dari orang tua berpotensi besar menyerang pada anak dengan berat badan berlebih khususnya selama proses kehamilan. Deckelbaum dan Williams (2001) menyebutkan bahwa diabetes dan obesitas merupakan faktor independent terhadap resiko kedaan tidak sehat dan kematian dalam siklus kehidupan. Wabah obesitas telah mengambil bayak korban pada anakanak di seluruh dunia. Beberapa situasi (penyakit) dihubungkan dengan masalah diabetes dan obesitas bahkan berdampak pada ganguan kronis jangka panjang. Disebabkan kelebihan berat badan, hari ini anak-anak hidup dengan usia lebih pendek dibandingkan orang dewasa.

Overweight dan obesitas menjadi penyumbang utama terhadap tingginya resiko kesehatan dan kematian yang berdampak pada semua lapisan usia dewasa hingga anak-anak. Usaha untuk mengakhiri, menurunkan dan mencegah prevalensi kenaikan berat badan khususnya pada anak usia dini terus gencar dilakukan termasuk diantaranya dengan melakukan identifikasi faktor-faktor penyebab meningkatnya overweight dan obesitas dengan harapan dapat memperkecil ruang lingkup masalah dan memberikan solusi tindakan preventif.

Dehghan et al (2005) menyatakan berat badan berlebih secara sederhana diartikan dengan banyak persentase lemak pada tubuh. Meskipun banyak definisi tentang berat badan berlebih, Kehoe et al. (2008). Menjelaskan secara umum dapat dijelaskan dengan meningkatnya lemak tubuh. Berat badan diklasifikasikan overweight jika melebihi $10 \%$ dari berat badan normal dan diklasifikasikan obesitas jika melebihi dari overweight atau diatas $10 \%$ dari berat badan normal yang dapat diukur menggunakan Indeks Massa Tubuh atau Tinggi Badan dikurangi 100. Selain persentase jumlah lemak, keseimbangan antar energi yang masuk dan energi yang keluar menentukan keseimbangan berat badan. Berat badan berlebih menandakan energi yang masuk lebih banyak dari pada energi yang keluar. Pada anak usia dini, pengukuran berat badan berbeda dengan orang dewasa. Pada anak usia dini penghitungan berat badan mengacu pada standar yang telah ditetapkan oleh Kementerian Kesehatan tentang standar antropometri penilian gizi anak yang diukur dengan dua cara yakni Berat Badan menurut Tinggi Badan (BB/TB) dan Indek Mass Tubuh (khusus balita) menurut umur.

Seperti yang telah dijelaskan sebelumnya, berat badan berlebih (overweight dan obesitas) dikaitkan dengan resiko kesehatan. Feldstein et al (2014) menjelaskan semakin tingginya obesitas pada anak maka akan semakin tinggi pula resiko kesehatan. Diperkuat oleh Grant-Guimaraes et al. (2016) yang menyatakan anak anak dengan overweight / obesitas memiliki resiko mengembangkan gangguan jangka panjang dan jangka pendek baik fisik maupun psikologis. Sejalan dengan teori yang dijelaskan sebelumnya Sherman et al. (2010) menyatakan obesitas dan komorbiditas utamanya telah menjadi tantangan kesehatan global utama yang mempengaruhi anak-anak dan remaja dari segala usia. Obesitas memiliki karakteristik tersendiri. Anak-anak dengan masalah overweight/obesitas cendrung akan mengalami overweight/obesitas diusia remaja.

Meningkatnya angka kematian mendadak yang diakibatkan gangguan kardiovaskular telah dihubungkan secara akurat bahwa kelebihan lemak tubuh terutama low deposity lipoprotein memicu plak di pembuluh darah arteria koronari sehingga menyebabkan penyumbatan darah untuk mensuplai oksigen ke jantung. Kelebihan lemak sendiri merupakan akibat dari berat badan berlebih. Overweight /obesitas memiliki kaitan erat dengan sejumlah komorbiditas pada anak bahkan anak-anak memiliki efek yang lebih buruk dari pada orang dewasa. Pada beberapa kasus, gejala yang dialami oleh anak-anak terhadap gangguan kardiovaskular sama dengan yang dialami oleh orang tua. Menurut Daniels et al. (2005) hasil informasi menujukan gangguan kardiovaskular dapat dimulai pada usia anak-anak tetapi baru terdeteksi pada saat dewasa

Selain gangguan kardiovaskular, gangguan pada sistem respirasi atau pernafasan paling sering dialami pada anak dengan overweight dan obesitas, yaitu asma. Asma merupakan penyakit kronis yang umum menyerang anak-anak. Wibowo dan Kushartanti (2013) menjelaskan bahwa asma merupakan salah satu penyakit gangguan pernafasan yang dapat menggangu semua aktivitas manusia. Peningkatan 
jumlah obesitas dan overweight sejalan dengan meningkatnya penderita asma pada anak-anak. Beberapa hasil penelitian menyimpulkan terdapat hubungan antara asma dengan anak-anak dengan masalah overweight dan obesitas. Teori patofisiologis potensial menjelaskan hubungan antara obesitas dan asma yaitu proses inflamasi kronis yang diciptakan oleh aditif yang berlebihan terlibat sebagai faktor yang mendasari patogenesis asma. Peningkatan massa lemak dikaitkan dengan peningkatan mediator inflamasi sistemik yang dapat memperburuk inflamasi jalan nafas melalui mediator inflamasi seperti leptin, adiponektin, Interleukin-6 (IL-6) dan Tumor Necrosis Factor-alpha (TNF- $\alpha$ ).

Willeboordse et al (2013) menjelaskan beberapa penelitian mencatat bahwa efek proinflamasi dari serum leptin dapat memodulasi inflamasi jalannya pernafasan. Gangguan pernafasan lainnya pada anak dengan overweight dan obesitas pada saat melakukan aktivitas fisik seperti seperti berlari dan melompat. Tarikan nafas yang tersengal-sengal menujuk jumlah asupan oksigen yang tidak optimal. Lebih dari $80 \%$ anak dengan overweight dan obesitas mengalami penurunan aktivitas fisik/latihan sebanyak $15 \%$ dalam te daya tahan paru-paru dibandingkan hanya $40 \%$ pada anak dengan berat badan normal. Must dan Strauss (1999) menjelaskan bahwa kuat dugaan meningkatnya hiperaktif bronkus memungkinkan kontribusi pada penurunan toleransi latihan pada anak dengan overweight dan obesitas. Kondisi dilapangan menujukkan anak-anak dengan berat badan berlebih pada rentang usia 4-5 tahun cendrung mengalami penurunan aktivitas bermain di luar rumah dibandingkan anak dengan berat badan normal cendrung lebih aktif yang disebabkan kekhawatiran orang tua terhadap gangguan asma yang menyerang anak ketika bermain.

Selain gangguan kardiovaskular dan pernapasan, resiko diabetes masuk dalam daftar gangguan beresiko obesitas layak yang diwaspadai. Anak dengan berat badan berlebih memiliki potensi mengalami resiko diabetes II yang lebih tinggi khususnya ketika memasuki fase dewasa yang diperburuk dengan riwayat keturunan atau faktor heriditas dimana orang tua memiliki riwayat diabetes maka potensi faktor penyakit yang diturunkan lewat keturunan selama proses kehamilan menjadi lebih tiggi.

Resiko diabetes pada anak dengan overweight dan obesitas layak diwaspadai. Anak dengan berat badan berlebih memiliki potensi mengalami diabetes II yang lebih tinggi. Terlebih lagi jika orang tua memiliki riwayat diabetes maka potensi faktor penyakit yang diturunkan lewat keturunan selama proses kehamilan menjadi lebih tiggi. Anak usia dini merupakan anak dalam fase pra-sekolah. Beberapa ahli menyebutkan klasifikasi umur untuk anak usia dini dari 0-8 tahun sedangkan dalam pandangan lain menyebutkan 0-6 tahun. Namun secara umum diklasifikasi pada rentang usia 0-8 tahun dengan spesikasi khusus 3-6 tahun. Hal ini didasarkan pada kebijakan pemerintah yang membagi klafikasi anak berdasarkan jenjang usia dimulai dari bayi, balita, usia dini dan anak-anak yang dihubungkan dengan jenjang pendidikan yaitu Pendidikan Anak Usia Dini (PAUD), Taman Kanak-kanak (TK) dan Sekolah Dasar (SD).

Dalam pendidikan jasmani, fase tumbuh kembang anak usia dini menekankan pada perkembangan motorik halus dan kasar yang terintegrasi dengan kemampuan berfikir, sikap sosial, tanggung jawab, jujur, sportif dan terutama kebugaran dan kesehatan. Sangat penting menjaga kebugaran dan kesehatan jasmani selama fase usia dini agar dapat bermain dan melakukan berbagai aktivitas fisik dengan cara menjaga berat badan agar tetap normal.

Seiring berkembanganya zaman, faktor gaya hidup ikut berperan menyebabkan tingginya angka orang dengan obesitas khususnya pada anak-anak. Sanusi (2020) mengartikan gaya hidup sebagai perilaku hidup sehari-hari atau dapat dikatakan sebagai kebiasaan. Menjalankan gaya hidup akan menjadi mudah karena proses ini merupakan bagian aktivitas yang dilakukan setiap hari. Gaya hidup sangat erata dikaitan dengan mengatur pola makan dan aktivitas fisik. Dua bagian ini menjadi variabel penting yang mempengaruhi keadaan berat badan, khususnya pada anak usia dini. Terutama kebiasaan hidup sehat dengan rutin melakukan aktivitas fisik dan olahraga atas dasar kesadaran untuk mendapatkan hidup yang lebih berkualitas. Perubahan paling mendasar dari gaya hidup adalah adalah fenomea sedenter yaitu kendrungan incativity atau rendahnya dalam melakukan aktivitas fisik.

Di era modern ini, obesitas merupakan ancaman disemua tingkatan usia yang menganggu kesehatan termasuk pada anak usia dini. Menanggapi hal itu, pemahaman orang tua sangat diperlukan untuk tidak menganggap obesitas pada anak adalah hal yang biasa. Penelitian ini dilakukan atas dasar kekhawatiran melihat angka kegemukan pada anak usia dini cukup tinggi. Dengan penelitian ini akan diperoleh informasi tentang faktor-faktor apa saja yang menyebabkan kenaikan berat badan pada anak usia dini, sehingga dapat dipahami dan diantisipasi oleh orang tua terhadap pola asuh anak khususnya dalam 
Jurnal Keolahragaan 8 (2), 2020 - 111

Rahmat Sanusi, Widiyanto Widiyanto, Ronny Brayntin Rahail

menjaga kesehatan anak dalam gaya hidup yang mencakup pola makan (junk food), minim aktivitas fisik (ketergantungan dengan smart phone).

\section{METODE}

Desain penelitian ini adalah analisis kuantitatif dengan desain cross sectional yaitu penelitian dan pengamatannya dilakukan secara simultan dalam satu waktu secara bersamaan. Cross sectional merupakan penelitian observasional yang mengumpulkan banyak data untuk pada satu titik yang melibatkan subjek penelitian guna mendapatkan data. Data yang diperoleh akan digunakan untuk menganalisa antar kasus. Umumnya analisa dilakukan hanya untuk satu kasus namun dibahas secara mendalam. Karakteristik dari cross sectional adalah penelitiannya berdasarkan pengamatan yang dilakukan secara Bersamaan dan silmultan. Dalam penelitian ini menekankan pencarian informasi sebanyak mungkin yang berpotensi memberikan efek/ dampak terhadap varibel dependen, meskipun terdiri dari banyak bagian variabel namun tetap difokuskan pada satu kasus. Teknik analisa data yang digunakan dalam penelitian ini adalah teknik analisa data multivariat regresi liner berganda. Teknik analisa data multivariat merupakan analisa statistik yang ditujukan untuk menganalisa data yang terdiri dari banyak variabel dan diduga setiap variabel saling berkaitan. Analisis multivariat digunakan untuk melihat hubungan variabel independent (covarian) terhadap variabel dependent. Dalam regresi linear berganda ditujukan untuk menganalisa faktor-faktor dari variabel independent guna mendapatkan informasi penyebab timbulnya masalah atau membantu menemukan informasi. Dengan kata lain regresi linear berganda melibatkan lebih dari satu variabel bebas atau predictor untuk melihat hubungannya dengan satu variabel terikat.

Penelitian ini dilakukan di sekolah PAUD dan TK yang berada di lingkungan Kabupaten Karimun Provinsi Kepulauan Riau. Teknik pemilihan sampel dilakukan dengan menggunakan teknik purposive sampling, artinya pemilihan sampel berdasarkan pertimbangan tertentu yaitu sempel yang mengalami kelebihan berat badan atau obesitas. Sampel penelitian dalam penelitian ini berjumlah 66 orang anak laki-laki usia dini dengan rentang usia 3- 5 tahun.

Pengumpulan data dilakukan dengan dua cara. Pertama, melakukuan pengukuran berat badan orang tua dan anak. Pengukuran berat badan dilakukan berdasarkan standar kesehatan Kementerian Kesehatan tentang standar antropometri penilaian gizi anak yang diukur dengan dua cara yakni Berat Badan menurut Tinggi Badan (BB/TB) dan Indek Mass Tubuh (khusus balita) menurut umur. Kedua, wawancara dengan orang tua terkait aktivitas dan pola makan anak.:

Tabel 1. Standar Berat Badan Anak Menurut Kementrian Kesehatan

\begin{tabular}{crr}
\hline Usia & \multicolumn{3}{c}{ Jenis Kelamin } \\
\cline { 2 - 4 } 1 th & Perempuan & Laki-laki \\
2 th & $7-11.5 \mathrm{~kg}$ & $7.7-12 \mathrm{~kg}$ \\
3 th & $9-14.8 \mathrm{~kg}$ & $9.7-15.3 \mathrm{~kg}$ \\
4 th & $10.8-18.1 \mathrm{~kg}$ & $11.3-18.3 \mathrm{~kg}$ \\
5 th & $12.3-21.5 \mathrm{~kg}$ & $12.7-21.2 \mathrm{~kg}$ \\
\hline
\end{tabular}

\section{HASIL DAN PEMBAHASAN}

\section{Hasil}

Dalam penelitian ini melibatkan 66 sampel berusia 3-5 tahun. Peneliti melakukan pengamatan langsung dengan mengukur berat badan dan mengajukan beberapa pertanyaan terkait orang riwayat tua dengan overweight/obesitas, pola makan dan aktivitas fisik anak. Hasil data dianalisa dengan menggunakan teknik analisa multivariat. Analisis multivariat digunakan untuk melihat hubungan variabel independent (covarian) terhadap variabel dependent. Distribusi frekuensi masing-masing varibel independent yaitu faktor keturunan (orang tua atau salah satu orang tua memiliki riwayat overweight atau tidak overweight), pola makan, dan tingkat aktivitas fisik seperti terlihat pada Tabel 2.

Berdasarkan hasil analisa mutlivariat pada Tabel 2, diperoleh data, variabel faktor keturunan memperoleh persentase sebanyak 53\%. Nilai $p$ diperoleh sebesar 0.046 yang menujukkan $p<$ dari 0.05 mengindikasikan terdapat hubungan yang signifikan antara gen/ terhadap kenaikan berat badan dengan perolehan nilai odds ratio sebesar 3.7 yang berarti anak dengan orang tua yang memilki masalah berat 
Jurnal Keolahragaan 8 (2), 2020 - 112

Rahmat Sanusi, Widiyanto Widiyanto, Ronny Brayntin Rahail

badan badan memiliki resiko $3 \mathrm{x}-4 \mathrm{x}$ lebih tinggi dari pada anak dengan orang tua yang tidak memiliki masalah berat badan.

Tabel 2. Hasil Analisis Multivariat Kenaikan Berat Badan Pada Anak Usia Dini Identifikasi Faktor Penyebab

\begin{tabular}{lcccc}
\hline \multirow{2}{*}{ Variabel } & \multicolumn{5}{c}{ Resiko Berat Badan Berlebih (Overweight \& Obesitas) } \\
\cline { 2 - 5 } & $\mathrm{N}$ & $\%$ & P Value & Odds Ratio \\
\hline Faktor Keturunan/Orang Tua & 53 & & 3.7 \\
$\begin{array}{l}\text { Beresiko } \\
\text { Tidak }\end{array}$ & 35 & 47 & 0.046 & \\
\hline $\begin{array}{l}\text { Pola Makan } \\
\text { Tinggi }\end{array}$ & 31 & 65.2 & & 2.8 \\
Rendah & 23 & 44.8 & 0.024 & \\
\hline Aktivitas Fisik & 36 & 54.5 & & 2.8 \\
Rendah & 30 & 45.5 & 0.028 & \\
Tinggi & & &
\end{tabular}

Variabel kedua adalah pola makan dengan persentase tertinggi yaitu sebesar $65.2 \%$. Nilai p diperoleh sebesar 0.024 yang menujukkan $p<0.05$ mengartikan bahwa terdapat hubungan yang siginifkan antara pola makan terhadap kenaikan berat badan pada anak usia dini dengan nilai OR sebesar 2.8 yang artinya, anak dengan pola makan tinggi memilki resiko $3 x$ lebih besar dari pada anak dengan pola makan rendah terhadap kenaikan berat badan.

Variabel terakhir adalah adalah aktivitas fisik dengan persentase sebesar $54.5 \%$. Nilai p diperoleh sebesar 0.028 yang menunjukan $\mathrm{p}<$ dari 0.05 mengindikasikan terdapat hubungan yang siginifkan antara aktivitas fisik dan kenaikan berat badan. Nilai odds ratio sebesar 2.8 yang artinya anak dengan aktivitas fisik rendah memiliki resiko 3x lebih tinggi kenaikan berat badan dibandingkan anak dengan aktivitas fisik tinggi.

\section{Analisis Multivariat}

Berdasarkan analisis multivariat diperoleh informasi bahwa penyebab kenaikan berat badan pada anak usia dini dipengaruhi oleh keturunan/gen dari orang tua, rendahnya aktivitas fisik dan pola makan. Intensitas aktivitas fisik menjadi variabel yang memperoleh presentase paling tinggi penyumbang kenaikan berat pada anak usia dini sedangkan untuk frekuensi resiko variabel faktor keturunan/gen lebih dominan dengan frekuensi resiko sebesar 3-4x.

\section{Pembahasan}

Masalah kenaikan berat badan menjadi permaslahan serius yang telah banyak didiskusikan pada dalam forum-forum kesehatan dunia. Silent killer, sepertinya prediket yang tepat untuk dilekatkan pada Overweight dan obesitas, mengingat dampak saat ini begitu drastis terhadap resiko kesehatan yang mencakup semua lapisan, khususnya anak dengan usia pra-sekolah. Sejalan dengan temuan Lanigan et al. (2019) obesitas telah menjadi gangguan global yang mengarah pada kondisi patologis. Sedikitnya di United Kingdom dari 1 dari 5 anak mengalami overweight dimulai pada masa awal sekolah.

Upaya pencegahan telah dilakukan secarater struktur namun tidak memberikan dampak yang signifikan terhadap penurunan prevalensi overweight dan obesitas. Ini disebabkan masih rendahnya kesadaran dan pemahaman orang tua terhadap standar berat badan ideal anak. Paparan pembahasan di atas menjelaskan bahwa terdapat tiga faktor utama sebagai penyebab kenaikan berat pada anak. Penurunan aktivitas fisik menempati persentase tertinggi terhadap kenaikan berat badan pada anak usia dini. sejalan dengan kajian teoritis tentang expenditure enery, yang membahas keseimbangan antara energi yang masuk dan keluar melalui aktivitas fisik. Hal ini diperkuat pada anak usia dini menekankan tumbuh dan kembang melalui model eksplorasi dengan cara bermain untuk meningkatkan kapasitas gerak motorik dasa dimana setiap aktivitas geraknya dihitung sebagai upaya pengeluaran energi.

Dalam ilmu keolahragaan anak usia dini diarahkan pada aktivitas fisik untuk mengembangkan kemampuan motorik kasar, seperti: berlari, melompat, melembar, menangkap dan lain sebagainya yang tergabung dalam kegiatan bermain baik secara individu maupun berkelompok. Aktivitas fisik memberikan sejumlah manfaat, yaitu tubuh yang ideal, tekanan darah rendah untuk memperbaiki kesehatan mental dan fisilogis. Ajay (2011) menyatakan Aktivitas fisik termasuk di dalamnya permainan yang mengan- 
Jurnal Keolahragaan 8 (2), 2020 - 113

Rahmat Sanusi, Widiyanto Widiyanto, Ronny Brayntin Rahail

dung fungsi yang diartikan dalam bentuk sosial, latihan meningkatkan kemampuan fisik dan kebugaran, mengembangkan karater serta mengupayakan kesehatan fisik dan mental. Tingkat aktivitas fisik menentukan pengeluaran energi yang terhubung dengan metabolisme, sehingga semakin tinggi aktivitas anak semakin besar tinggi metabolisme tubuh yang berdampak besarnya pengeluaran energi sehingga mempengaruhi tingkat kebugaran jasmani. Prastiwi dan Suharjana (2014) Kebugaran jasmani pada anak usia dini bukan ditujukan pada hasil melainkan proses. Prosesnya adalah memberikan anak Pengalaman dalam beraktivitas mengajarkan mengenai penggunaan tenaga yang bermanfaat, belajar bertanggung jawab, dan bergaya hidup sehat. Pelajaran yang didapat dari kehidupan sehari- hari untuk mendapatkan kebugaran jasmani yang baik adalah aktivitas fisik atau olahraga 2-5 kali seminggu selama 30-45 menit disamping pembelajaran fisik motorik di sekolah. Memperkuat pendapat di atas, Suyatmin dan Widiyanto, (2017) menjelaskan bahwa upaya pencegahan penyakit telah diajarkan sejak dini pada anak melalui penanaman perilaku hidup sehat yang menjadi bagian dari pembelajaran di Taman Kanak-kanak (TK). Dengan meningkatnya pemahaman hidup bersih dan sehat, proses ini diharapkan menjadi kesadaran dan kebiasaan pada anak dalam menjaga meningkatkan kesehatan khususnya mencegah kegemukan.

Sherman et al. (2010) perkembangan trend saat ini menjadi penyebab ketidakaktifan aktivitas fisik dan pola makan yang tidak sehat menyebabkan 300 ribu anak-anak meninggal setiap tahunnya. Laporan lain menujukkan anak-anak yang mengalami obesitas diestimasi jumlahnya akan meningkat lebih dari 2x lipat dalam 25 tahun ke depan. Kondisi ini sangat memperhatikan sejalan dengan pendapat Corvalán et al. (2017) bahwa lebih dari 20\% anak-anak di Amerika Latin yang diperkirakan tidak kurang dari 42.5 juta anak-anak usia 0-19 tahun mengalami overweight hingga obesitas. Dalam kurun 10 tahun terakhir, sosioekonomi, budaya, urban dan geografis diyakini telah meningkatkan ganguan obesitas.

Dari sekian banyak faktor penyebabkan kenaikan obesitas pada anak, pemicu utamanya adalah ketidak seimbangan energi yang masuk dan keluar. Meskipun metabolis ikut berpengaruh terhadap pengeluaran energi, namun akitvitas fisik membutuhkan banyak energi untuk melakukan aktivitas seharihari. Esparza et al. (2000) menjelaskan kenaikan berat badan akan terjadi jika terjadi peningkatan energi yang dibutuhkan dari pada energi yang dikeluarkan. Diperkuat oleh Amen-Ra et al. (2012) bahwa sangat jelas bahwa aktivitas fisik memberikan keseimbangan energi untuk menekan resiko kesehatan akibat penumpukan energi. Aktivitas fisik mengatur keseimbangan pengeluaran energi (energi expenditure) untuk meningkatkan kesehatan inividu. Sejalan dengan pernyataan sebelumnya May (2006) menjelaskan meskipun perilaku dan lingkungan sosial menjadi faktor masalah obesitas yang sangat kompleks akar permasalahannya sangat sederhana yaitu energi yang masuk lebih banyak dari pada energi yang dikeluarkan sehingga berdampak postif terhadap penyebab obesitas dalam periode jangka waktu yang lama, dengan kata lain kunci untuk menekan kenaikan berat badan adalah energi yang keluar harus lebih banyak dari energi yang masuk.

Surflus energi bertanggung jawab terhadap kenaikan berat pada anak. Surflus energi seharusnya digunakan untuk pertumbuhan normal, kegiatan aktivitas sehari-hari yang diperkirakan 110 -165 kalori per hari. Pada anak overweight/obesitas terjadi ketidakseimbangan akumulasi energi diperkirakan 600 - $1100 \mathrm{kcal}$ per hari. Indikatronnya adalah ketidak aktifan anak selama waktu luang (Bleich et al., 2011). Perubahan kebutuhan energi ini terjadi karena perubahan pola makan pada anak. Produk-produk dengan kadar tinggi gula dan lemak cendrung menjadi tren pola makan pada anak yang diperburuk dengan rendahnya pemahaman orang tua terhadap kandungan nutrisi dan pola makan. Mencegah kenaikan berat badan pada anak tidak dapat dilepaskan dari upaya mengatur pola makan. Perlu sinergi yang jelas dalam menyusun program makan yang terdiri dari jenis makanan dan waktu makan. Sanusi (2020) menjelaskan bahwa pola makan merupakan aktor penting yang dikaitkan dengan gaya hidup dan kebugaran, sehingga pemilihan dan pengolahan makanan mempengaruhi kondisi tubuh.

Henriksen (2008) menjelaskan bahwa makanan cepat saji ditawarkan dengan bentuk yang menarik dan rasa yang enak dengan kandungan lemak, kolestrol dan yodium yang tinggi namun rendah pada kandungan serat dan kalsium. Pemahaman pengaturan kebutuhan nutrisi oleh orang tuamerupakan keharusan. Salah satu pemicu obesitas pada anak adalah malnutris, yang diartikan ketidakseimbangan sistem metabolisme tubuh dalam mengatur nutrisi. Beberapa bukti menunjukkan kekurangan gizi imunosupresi, yaitu kerentanan terhadap infeksi atu kekurusan. Sebaliknya, kelebihan gizi menyebabkan imunoactivition, yakni kerentanan pada kondisi peradangan. Program penurunan berat badan, aktivitas fisik tidak dapat dijadikan solusi untuk mengurangi lemak tubuh. Hampir rata-rata orang memilih olahraga di pusat kebugaran sebagai program penurunan bera badan, namun hanya mengalami penurunan berat 
badan sebesar 1 ons/peminggu. Hal ini disebabkan tidak memiliki pola diet unuk mengatur kebutuhan energi.

Pemahaman orang tua dalam pengaturan pola makan pada anak adalah pengetahuan penting. Terutama jika berkaitan dengan sindrom metabolisme. Sindrom metabolisme adalah perbedaan sistem metabolisme pada tubuh yang berpengaruh pada intake dan output energi. Anak dengan metabolisme rendah akan cepat mengalami kenaikan berat badan meskipun makan dalam jumlah sedikit, sebaliknya anak dengen metabolisme tinggi tidak akan mengalami kenaikan berat badan yang signifikan meskipun makan dalam jumlah banyak. Pada metabolisme rendah proses pengolahan energi relatif lebih lambat dan pada metabolisme tinggi proses pengeolahan energi relatif lebih cepat. Kedua perbedaan ini akan berpengaruh pada kebutuhan dan pengeluaran energi. Dalam analogi sederhana jika anak dengan metabolisme tinggi dan rendah makan sebanyak 100 kalori, anak metabolisem tinggi akan mengeluarkan sebanyak 60 kalori dan 40 akan disimpan sebagai cadangan energi. Sebaliknya, pada anak dengan metabolisme rendah energi yang dikeluarkan sebayak 40 kalori dan sebanyak 60 kalori energi akan disimpan sebagai cadangan. Banyak kasus menunjukan orang dengan kelebihan berat badan dan obesitas didominasi orang dengan metabolisme rendah. Pengeluaran energi yang sedikit, cadangan energi yang banyak, minimnya aktivitas fisik serta pola makan tinggi lemak semakin meningkatkan resiko obesitas.

Faktor keturunan ikut berperan terhadap kenaikan berat badan. Orang tua dengan berat badan berlebih (ayah atau ibu atau keduanya) memberikan dampak langsung terhadap kenaikan berat badan anak. Masa kehamilan, pola asuh dalam lingkungan keluarga menjadi indikator kuat dalam kasus ini. Selama proses Ibu kehamilan, ibu dengan kondisi overweight/obesitas memiliki potensi lebih tinggi menurunkan gen overweight/obesitas melalui metabolisme, sel lemak dan lain sebagainya. Anak yang lahir dari ibu dengan overweight/obesitas cendrung mengalami peningkatan lemak tubuh pada saat lahir dan resiko obesitas. Menurut Vause et al. (2006) penelitian di Canada menunjukkan seorang wanita dengan berat badan sebelum hamil $90 \mathrm{~kg}$ dan kenaikan berat badan sebesar $18 \mathrm{~kg}$ saat hamil terbukti memiliki fektor resiko autis terhadap janin. Moss dan Chugani (2014) menambahkan selama proses kehamilan, pertumbuhan janin bergantung pada ibu. Pola makan, tingkat stres, aktivitas dan genetik ibu menyumbang dalam proses tersebut. Henriksen (2008) menjelasskan bahwa hasil penelitian menyebutkan, bayi yang lahir dengan berat yang besar dan ibu dengan riwayat diabetes sekaligus obesitas Ibu dengan riwayat diabetes dan obeistas Selain faktor ibu kehamilan, lingkungan keluarga ikut mempengaruhi kenaikan berat badan memiliki resiko yang tinggi terhadap sindrom metabolisme.

Salah satu orang tua atau keduanya dengan masalah berat badan secara langsung memberikan contoh yang tidak baik. Malas berolahraga, kebiasan buruk merokok/ alkohol dan pola makan yang tidak teratur adalah beberapa contoh dari sekian banyak situasi lingkungan keluarga yang tidak sehat. Lingkungan keluarga merupakan proses simulasi bagi anak untuk mencontoh setiap tindakan orang tua seperti olahraga dan aktivitas fisik. Sejalan dengan istilah "children see and children do" yang mengindikasikan orang tua memberikan ruang contoh terhadap kesehatan anak. Memasuki era urban saat ini, pola asuh orang tua terhadap tumbuh kembang anak dan keterlibatannya secara langsung cukup mengkhawatirkan. Orang tua memilih gadget untuk menangkan anak dari pada ikut bermain bersama anak. Gadet menjadi solusi untuk menekankan keaktifkan anak dalam bereksplorasi, dengan gadget anak menjadi lebih tenang/cederung diam dan tidak banyak bergerak karena gadget menyajikan tontonan dan game yang menarik. Kondisi ini adalah realita bahwa seiring berkembang dan majunya teknologi berdampak terhadap resiko pola hidup yang berpengaruh pada resiko kesehatan yakni penurunan aktivitas fisik. Termasuk keterlibatan orang tua untuk mengisi waktu luang dengan melakukan aktivitas fisik bersama anak. Aktivitas fisik tidak harus berolahraga di pusat kebugaran. Berjalan kaki pagi dan sore hari, joging diwaktu libur atau bermain di luar rumah bersama anak merupakan langkah awal edukasi dini dalam mengenalkan aktivitaas fisik untuk menjaga pola hidup sehat melalui keseimbangan energi.

Penurunan berat badan tidak akan tercapai jika aktivitas fisik/olahraga tidak diimbangi dengan kebutuhan energi Fock dan Khoo (2013). Penting untuk orang tua memahmi karaterisktik makan pada anak. Diet bukan tentang membatasi makan, tetapi upaya menjadikan proses makan lebih berkualitas dan bermanfaat bagi tubuh, khususnya pada anak-anak. Paparan tersebut menunjukkan nutrisi yang optimal diperlukan untuk tercapainya keseimbangan dan kesehatan. Lee et al. (2013) menjelaskan bahwa aktivitas fisik dan pola makan menjadi dua sisi mata koin yang berbeda namum tidak dapat dipisahkan. Sesuai dengan pengertian menjaga berat badan ialah mengatur keseimbangan energi yang masuk dan keluar. Tanpa makan tubuh tidak memiliki energi untuk melakukan aktivitas, sebaliknya jika pola makan yang tinggi maka dapat dipastikan jumlah asupan energi yang masuk juga sedikit. Penurunan aktivitas 
fisik membuat surflus cadangan energi yang semakian lama menumpuk dan menyebabkan kegemukan. Hasil di lapangan menunujukkan anak dengan berat badan berlebih memiliki beberapa karakteristik tentang pola makan, yaitu selera makan yang tinggi, jenis makan tidak sehat yang cendrung makanan dengan rasa manis dan lemak serta rendahnya pengetahuan orang tua terkait pola/ jenis makan. makanan cepat saji menjadi salah satu sumber yang menyebabkan prevalensi obesitas meningkat.

Era urban memberikan dampak perubahan perilaku pada kondisi sosial dimana ebiasaan sedenter menjadi hal yang biasa. Ketergantungan pada smart phone menyebabkan lebih banyak menghabiskan waktu dengan bermain game sedikitnya 1 hingga 4 jam/hari. Tidak terkecuali pada anak usia dini yang menjadikan gandet sebagai media bermain yang difasilitasi oleh orang tua. Kondisi ini tentunya bertolak belakang dengan tuntutan perkembangan anak yang seharusnya dijalani sesuai dengan perkembangan usia. Aktivitas fisik seperti bermain di luar rumah guna merangsang perkembangan kognitif, afektif dan psikomotor sangat diperlukan untuk menciptakan keseimbangan energi guna mencegah obesitas.

Berdasarkan paparan penjelasan di atas, tidak dapat dipungkiri ketiga faktor tersebut merupakan hasil identifikasi penyebab kenaikan berat badan pada anak. Faktor heriditas menyebabkan anak berpotensi mendapatkan gangguan metabolis yang didukung dengan penurunan aktivitas fisik sehingga terjadinya surflus energi akibat pola makan yang tidak teratur.

\section{SIMPULAN}

Pencegahan masalah berat badan berlebih yaitu overweight sangat perlu dilakukan sedari awal khususnya pada anak usia dini. Anak merupakan aset dan penerus bangsa yang perlu dijamin kesehatannya terutama jaminan untuk mendapatkan lingkungan yang sehat. Apa yang terjadi jika prevalensi overweight dan obesitas pada anak usia dini meningkat berkali lipat dalam beberapa tahun kedepan. Tentunya akan menjadi permasalahan serius seperti bom waktu yang hanya menunggu waktu kapan akan meledak. Salah satu upaya pencegahan overweight/ obesitas adalah melakukan pendekatan yang mencakup semua lapisan yakni pendidikan, sosial hingga spiritual. Khususnya dalam meningkatkan pemahaman dan membangun kesadaran masyarakat melalui identifikasi-identifikasi penyebab overweight dan obesitas, dengan demikian resiko kenaikan berat badan pada anak dapat dicegah. Memahami penyebab kenaikan berat badan pada anak usia dini menjadi informasi tentang program pecegahan obesitas sedini mungkin.

\section{DAFTAR PUSTAKA}

Ajay, K. (2011). Importance of physical education, games \& sports activities. VSRD Technical \& NonTechnical Journal, 2(11), 570-573.

Amen-Ra, N. S.-S., Velasco-Mondragon, E., Hossain, M. B., \& Bronner, Y. (2012). Energy expenditure differs between black and white Americans: Implications for obesity prevention research. Food and Nutrition Sciences, 03(07), 914-924. https://doi.org/10.4236/fns.2012.37121

Bleich, S. N., Ku, R., \& Wang, Y. C. (2011). Relative contribution of energy intake and energy expenditure to childhood obesity: a review of the literature and directions for future research. International Journal of Obesity, 35(1), 1-15. https://doi.org/10.1038/ijo.2010.252

Corvalán, C., Garmendia, M. L., Jones-Smith, J., Lutter, C. K., Miranda, J. J., Pedraza, L. S., Popkin, B. M., Ramirez-Zea, M., Salvo, D., \& Stein, A. D. (2017). Nutrition status of children in Latin America. Obesity Reviews, 18(July), 7-18. https://doi.org/10.1111/obr.12571

Daniels, S. R., Arnett, D. K., Eckel, R. H., Gidding, S. S., Hayman, L. L., Kumanyika, S., Robinson, T. N., Scott, B. J., St. Jeor, S., \& Williams, C. L. (2005). Overweight in children and adolescents. Circulation, 111(15), 1999-2012. https://doi.org/10.1161/01.CIR.0000161369.71722.10

de Onis, M., Blössner, M., \& Borghi, E. (2010). Global prevalence and trends of overweight and obesity among preschool children. The American Journal of Clinical Nutrition, 92(5), $1257-$ 1264. https://doi.org/10.3945/ajcn.2010.29786

Deckelbaum, R. J., \& Williams, C. L. (2001). Childhood obesity: The health issue. Obesity Research, 9(S11), 239S-243S. https://doi.org/10.1038/oby.2001.125

Dehghan, M., Akhtar-Danesh, N., \& Merchant, A. T. (2005). Childhood obesity, prevalence and 
prevention. Nutrition Journal, 4(1), 24. https://doi.org/10.1186/1475-2891-4-24

Esparza, J., Fox, C., Harper, I., Bennett, P., Schulz, L., Valencia, M., \& Ravussin, E. (2000). Daily energy expenditure in Mexican and USA Pima Indians: low physical activity as a possible cause of obesity. International Journal of Obesity, 24(1), 55-59. https://doi.org/10.1038/sj.ijo.0801085

Feldstein, A. E., Patton-Ku, D., \& Boutelle, K. N. (2014). Obesity, nutrition, and liver disease in children. Clinics in Liver Disease, 18(1), 219-231. https://doi.org/10.1016/j.cld.2013.09.003

Fock, K. M., \& Khoo, J. (2013). Diet and exercise in management of obesity and overweight. Journal of Gastroenterology and Hepatology, 28, 59-63. https://doi.org/10.1111/jgh.12407

Grant-Guimaraes, J., Feinstein, R., Laber, E., \& Kosoy, J. (2016). Childhood overweight and obesity. Gastroenterology Clinics of North America, 45(4), 715-728. https://doi.org/10.1016/j.gtc.2016.07.007

Güngör, N. K. (2014). Overweight and obesity in children and adolescents. Journal of Clinical Research in Pediatric Endocrinology, 6(3), 129-143. https://doi.org/10.4274/jcrpe.1471

Henriksen, T. (2008). Nutrition and pregnancy outcome. Nutrition Reviews, 64(5), S19-S23. https://doi.org/10.1111/j.1753-4887.2006.tb00241.x

Kehoe, S., Jauniaux, E., Martin-Hirsch, P., \& Savage, P. (2008). Cancer and reproductive health. RCOG.

Lanigan, J., Tee, L., \& Brandreth, R. (2019). Childhood obesity. Medicine, 47(3), 190-194. https://doi.org/10.1016/j.mpmed.2018.12.007

Lee, H., Lee, I. S., \& Choue, R. (2013). Obesity, inflammation and diet. Pediatric Gastroenterology, Hepatology \& Nutrition, 16(3), 143. https://doi.org/10.5223/pghn.2013.16.3.143

May, K. W. (2006). Exercise prescription-the physiological foundations: A guide for health, sport and exercise professionals (I). Elsevier Health Sciences.

Moss, B. G., \& Chugani, D. C. (2014). Increased risk of very low birth weight, rapid postnatal growth, and autism in underweight and obese mothers. American Journal of Health Promotion, 28(3), 181-188. https://doi.org/10.4278/ajhp.120705-QUAN-325

Must, A., \& Strauss, R. (1999). Risks and consequences of childhood and adolescent obesity. International Journal of Obesity, 23(S2), S2-S11. https://doi.org/10.1038/sj.ijo.0800852

Prastiwi, B. K., \& Suharjana, S. (2014). Pembuatan tes dan norma kebugaran jasmani untuk anak usia dini (4-6) tahun di Provinsi DIY. Jurnal Keolahragaan, 2(1), 22-31. https://doi.org/10.21831/jk.v2i1.2600

Sanusi, R. (2020). Identifikasi gaya hidup pra-lansia etnis Tionghoa dalam menjaga kesehatan dan kebugaran. Jurnal Endurance : Kajian Ilmiah Problema Kesehatan, 5(2), 180-193. http://ejournal.lldikti10.id/index.php/endurance/article/view/v5i2-4613

Sherman, C. P., Tran, C., \& Alves, Y. (2010). Elementary school classroom teacher delivered physical education: Costs, benefits and barriers. Physical Educator, 67(1), 2-17. https://js.sagamorepub.com/pe/article/view/2113

Suyatmin, S., \& Widiyanto, W. (2017). Pengembangan modul pembelajaran perilaku hidup bersih dan sehat pada taman kanak-kanak. Jurnal Keolahragaan, 5(1), 90. https://doi.org/10.21831/jk.v5i1.12807

Vause, T., Martz, P., Richard, F., \& Gramlich, L. (2006). Nutrition for healthy pregnancy outcomes. Applied Physiology, Nutrition, and Metabolism, 31(1), 12-20. https://doi.org/10.1139/h06-001

Wibowo, A. T., \& Kushartanti, B. M. W. (2013). Modifikasi permainan sepakbola bagi siswa SMA penderita asma. Jurnal Keolahragaan, 1(2), 104-119. https://doi.org/10.21831/jk.v1i2.2567

Willeboordse, M., van de Kant, K. D., de Laat, M. N., van Schayck, O. C., Mulkens, S., \& Dompeling, E. (2013). Multifactorial intervention for children with asthma and overweight (Mikado): study design of a randomised controlled trial. BMC Public Health, 13(1), 494. https://doi.org/10.1186/1471-2458-13-494 